\title{
Fire without Smoke
}

On January 19, 1999, a run-of-the-mill fight between a Protestant bus driver and a Muslim passenger escalated into a full-scale battle between what rapidly became designated as Christian "red" and Muslim "white" forces that was fought in the streets of Ambon with traditional or makeshift weapons-knives, spears, machetes, arrows shot from slingshots, fishing bombs, and Molotov cocktails. Occasionally, weapons like arrows were dipped in homemade poison to ensure their deadly impact. Overall, the violence in this initial phase of the war was remarkable for its ferocity, with the attacks and killings on both sides being especially horrific. By the end of the second day, numerous houses, stores, offices, churches, and mosques had been destroyed or burned and scores of people had been displaced, while others were wounded or killed. In the largely segregated city of Ambon, the kind of sectarian border skirmish that set all this off was common. Under normal circumstances, it would also have remained a nonevent-except, of course, for those immediately involved. Three years later, upon the signing of the Malino II Peace Agreement in early February 2002, the conflict had left the city radically transformed.

In what many scholars have identified as the first phase of the war, lasting from mid-January 1999 until May 2000, periods of violent confrontation between native Ambonese Protestant and Muslim mobs and mass destruction alternated with lulls in which attempts at reconciliation involving elite Ambonese from both sides were occasionally made. 'Jakarta's blunders also began early on, with the dispatch of the first troops to quell the violence from South Sulawesi-or that part of Indonesia from which the Muslim migrants driven out of Ambon during the conflict's first weeks also hailed-with shoot-on-sight orders and with a general lack of initiative and direction. Far from Jakarta still 
reeling from Reformasi's many upheavals, Ambon did not rank particularly high on anyone's priorities. What is more, the authorities' will to intervene also depended on their assessment of the seriousness of the situation. ${ }^{2}$ In the case of Ambon, many hoped it would simply blow over. ${ }^{3}$ This first phase was also marked by the outbreak of violence in the Kei Islands in southeast Maluku in April 1999 and in the soon-to-be-declared new province of North Maluku in August of the same year. ${ }^{4}$

The second phase marked a qualitative change in the conflict with the May 2000 arrival of the so-called Laskar Jihad in Ambon. ${ }^{5}$ Called into existence out of Muslims' rising concern that the Christians had the upper hand in the conflict, this militant Muslim organization with recruits from Java, Sumatra, and South Sulawesi provided both partisan humanitarian assistance and armed support. The Laskar Jihad emerged in the wake of a massacre of four hundred Muslims in a mosque in the town of Tobelo on the North Malukan island of Halmahera in late December 1999. ${ }^{6}$ News of the massacre spread rapidly via print media and, crucially, a VCD showing devastating scenes of the charred mosque interior littered with bodies, body parts, remnants of clothing, and other traces of the life that had once been there. ${ }^{7}$ A general call for jihad in Maluku followed shortly thereafter during a mass rally in Jakarta in early January 2000 under the auspices of such major national political figures as the country's former vice president Hamzah Haz and the People's Consultative Assembly Speaker Amien Rais. Several months later, on April 6, 2000, the announcement of the foundation of the paramilitary organization was staged as a spectacular event, a flamboyant display of numbers and Muslim power, as some ten thousand Laskar Jihad members demonstrated before the Presidential Palace, an image that became "etched in the minds of the Indonesian body politic."

The arrival of two thousand members of the Laskar Jihad in Ambon in May 2000 was no less momentous. The amount and sophistication of the weapons used in the war had grown over time, but the group brought a surplus of professional arms to Ambon, along with advanced radio communications technology. It also introduced some order into the local Muslim militias, who at least initially welcomed these supporters as heroes, and it enjoyed the clear backing of segments of the armed forces. The Christians found themselves significantly outnumbered and outgunned, and casualties and devastation increased proportionately. This is also when Catholics began to be drawn into the conflict-notwithstanding the effort of Ambon's bishop to play a mediating role-since the jihadis attacked Christians indiscriminately, making no distinction between Protestants and Catholics. ${ }^{10}$ By late June 2000, then president Abdurrahman Wahid announced a state of civil emergency in both Maluku 
and North Maluku provinces, and a special conjoined force of elite troops under a Balinese Hindu commander was dispatched to Ambon. If the declaration of the state of emergency greatly curtailed civil liberties - not the least of which being the press - and further enhanced the militarization of everyday life, it also gradually limited the number of large-scale confrontations.

This second phase of the conflict was further characterized by a deepening of the religious definition of the opposing parties and the crystallization of relevant extremist discourses ${ }^{11}$ - on the one hand, that of militant Islam and jihad, represented first and foremost by the Laskar Jihad and the smaller, more covert Laskar Mujaheddin, and, on the other, that of nostalgic sovereignty and separatism, embodied by the Christian Maluku Sovereignty Front (I. Front Kedaulatan Maluku, or FKM). Posing as the successor to the former separatist Republic of the South Moluccas movement (which in actuality exists primarily as a shadow of its former self among segments of the Malukan population in the Netherlands), the FKM envisioned its future as the nostalgic resurrection of an indigenous Malukan identity and boasted a leader who modeled himself after Xanana Gusmão, the former charismatic leader of Timor-Leste, which, at the time, was a very recent success story of national sovereignty.

By 2001, with the decrease of large-scale confrontations and their replacement by sporadic bombings and sniper attacks, the partial restraint of the Laskar Jihad under civil emergency conditions, and the signing of the Malino II Peace Agreement in South Sulawesi on February 12, 2002, the period of postviolence may be said to have begun. Civil emergency remained in effect, however, until mid-September 2003, along with the concomitant militarization of daily life and the restriction on foreign visitors to Maluku. The initial sense of relief in Ambon's streets following the Malino agreement was marred in the following months by intermittent explosions and attacks that many suspect were orchestrated by those who profit from the perpetuation of chronic, low-level violencesegments of the military and police, individual deserters from the same, local gangsters, militant groups, and possibly more shadowy protagonists. ${ }^{12}$ The influx of humanitarian aid and the presence of security forces in the city, along with lingering desires for revenge and religious militancy, further spurred profiteering on, resulting in "a well-funded industry of sporadic violence."13 For quite some time, the city remained divided into rigorously defended, religiously marked territories, or, as one source acutely observes, "concentrated pools of resentment and bitterness"-or, in other words, potential breeding grounds for more violence-alongside emerging neutral zones and places of resistance and peace. ${ }^{14}$ This, in broad strokes, is the war. Much has obviously been left out - not the least of which are the kinds of atmospherics with which I began this book. 


\section{War's Fog}

I was moved to write about the situation in Ambon several months after the Malino II Peace Agreement was signed and before returning to the city that I had visited off and on since 1984 en route to Aru in Southeast Maluku. Numerous others - in and around Ambon, in Jakarta, Manado, and elsewhere in Indonesia, and farther afield in Australia, the Netherlands, and the United States-had already written before I did, analyzing the conflict, its possible causes and myriad enabling conditions, and describing its protagonists, warring parties, and behind the scenes power plays, both local and national. They include anthropologists and other social scientists, within and outside Indonesia, activists and representatives of a range of local, national, and international NGOs, a number of the main players in the conflict, as well as media practitioners based in Ambon and the neighboring islands, the capital Jakarta, or abroad. My initial response was simply one of reaction to such assessments and reports and, notwithstanding the contribution and insights of many, some dissatisfaction with the overall story they told or, more pertinently, failed to tell about the city, its people, and the unfolding conflict among them. Much of what I wrote in 2002 still stands today and is therefore reproduced in an elaborated, updated version here. ${ }^{15}$

Ranging from highly engaged and informed analyses to the more codified versions of NGO-speak and the slanted partisan stories that bolster the truth claims of one or another side, the origins, complicating factors and backgrounds, major events, and relevant national and international developments have been scrutinized and amply discussed in terms of their respective contributions to Ambon's violence. As so many theatrical backdrops against which the main action unfolds, important externalities and internal factors named as enabling and providing fertile ground for the outbreak of Ambon's violence include such macropolitical and macroeconomic structures as the Southeast Asian financial crisis of 1997 and its aftermath, the unraveling of Suharto's New Order and the upheavals of Reformasi, and the behind-the-scenes connivings of Jakarta's political elite and the military. Tensions among Ambonese Christians and Muslims, more specifically, are seen as having been aggravated over the long term, as well as more recently by the religious division of labor established under Dutch colonial rule that privileged Christians and marginalized Muslims socially, economically, and educationally; by the parallel processes of Islamicization and Christianization in Maluku in the wake of World War II and the related erosion of the common ground of custom shared by Ambonese; and by the Islamicization of Indonesia generally under the late Suharto regime, as evidenced in Ambon by the appointment of two Ambonese Muslims as 
provincial governor, leaving the Christians feeling that they were left behind. Add to this the increasing shortage of land, population pressure, and the inmigration of Butonese, Buginese, and Makassarese Muslims from South Sulawesi, as well as those who benefitted from the New Order's immigration policies, ${ }^{16}$ skewing the once more or less equal numerical balance on the island between Christians and Muslims in favor of Muslims, and the involvement of some, especially urban Ambonese, in gangs and criminality, and one has a situation waiting to happen-waiting to happen perhaps, but still not yet, not quite, happening.

While many of the arguments and analyses produced over the years since the conflict began have added to my understanding of Ambon's conflict, I was troubled from the outset by the sense that something was missing. Some of this writing is just too grand, too abstract, and too removed from the volatile, fractured field where, throughout the violence, Ambonese men, women, and children pieced together their everyday lives out of the fears, contingencies, insecurities, and apprehensions that then weighed upon them. What tends to be passed over in foregrounding the influence of Indonesia's major political players, the networks of militant Muslims and Christian gangs and militias, the nefarious wheelings and dealings of thugs, the inbred violence, corruption, and partisan affections of the police and the military, is the character of the very space in which all of these figures, for better or for worse, deploy their schemes and make their dubious marks.

Elusive as this may sound, terms like climate, ambiance, atmospherics, and milieu, often invoked in descriptions of social and political violence, most closely approximate what I am getting at. If tangential, these terms still conjure and gloss the influence and effects of a certain presence that, while lacking any real precision, is understood, nonetheless, to have definitive power in the shaping of events, human agency and subjectivity, and the production of meaning. While relatively unstudied, this presence is a long-acknowledged condition of war. In the words of the nineteenth-century Prussian general and military theorist Carl von Clausewitz, referring to the uncertainty and challenge to perception posed by warfare, "All action takes place, so to speak, in a kind of twilight, which like a fog or moonlight, often tends to make things seem grotesque and larger than they really are." ${ }^{17} \mathrm{~A}$ key aspect of this process, as I elaborate below, is the emergence of extreme perception among many of the city's inhabitants, Muslims as well as Christians, in the form of an anxious play between efforts at acute seeing, on the one hand, and an overwhelming sense of unseeing or blindness, on the other. As the war went on, another component was the production of religion as a highly visible, public phenomenon that became crystallized in the marked contrast between Muslim and Christian 
opponents. In short, while my entry onto the scene of Ambon's violence may strike some readers as oblique or peripheral to the allegedly more central issues of politics, economics, and sociology-whether local, regional, national, or even international-my intention is to offer not only different ways of understanding but also different things to understand, as has been suggested is possible in the field of visual anthropology generally. ${ }^{18}$ This is because, as I argue in Chapter 2, the huge Christian pictures and the photographs featuring them and their makers are closely attuned to the affective dispositions and intensities of the street. What this book will add is not only attention to ordinary people and the predicaments they faced in a city at war but an understanding of the atmosphere that made elite manipulations effective, the change from neighborliness to paranoia plausible, and uncertainty a persistent ingredient of encounter and exchange. This atmosphere comprised everything from the myriad ephemeral mediations of war like graffiti and provocative pamphlets, which have received some attention from scholars, to much more difficult to grasp phenomena like Clausewitz's fog of war or the diffuse appearances that characterize, however tangentially, a given time and place.

A few caveats are in place. I do not mean to suggest that Indonesia is an especially or unusually violent country. A number of scholars have expressed concern about the centrality of violence as a topic of study following Suharto's fall from power. This, however, would seem to overlook how all the writing about violence represents an attempt to come to grips with the legacy of a regime that was itself inaugurated by extreme violence and that deployed violence strategically in the process of developing its particular brand of governmentality. Some ventured that writing about violence is itself laden with risk. An Indonesian colleague, for instance, in a private conversation with me, condemned the publications appearing on Ambon's conflict while it was still underway as unequivocally "written in blood." Other authors hastened to underscore how Indonesia's violence is neither novel nor recent but long-standing as they marshaled such glaring examples of New Order brutality-beyond its foundation on the "mountain of skeletons" left by the 1965-1966 massacres-such as the invasion of East Timor, the devastating military actions in Aceh and Papua, the surreptitious killing of alleged criminals in the 1980s by the regime, and the present-day impunity of the leaders and henchmen toward the events of

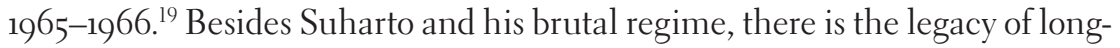
standing Dutch engagement in Maluku as part of the world's violently contested spice islands and what is today Indonesia, more generally, beginning in the sixteenth century under the Dutch East India Company. There is also the Japanese occupation from 1942 to 1945 when the revolutionary leaders Sukarno and Hatta declared Indonesia's independence, followed by the colonial war waged against the former Dutch colonizer from 1945 to $1949 .{ }^{20}$ 
Such legacies are legacies. Although they may fade and be transformed over time, they do not necessarily disappear but instead leave their mark in more obvious or subtle but, inevitably, complicated ways. Relevant in this regard is routine violence or the violence that is part and parcel of the production and continuity of contemporary political arrangements, or, put otherwise, the enabling conditions of what commonly counts as violence. ${ }^{21}$ Notwithstanding the dramatic changes wrought by the 1998 Reformasi movement and the farreaching nature of the national decentralization program launched shortly after Suharto's downfall, decentralization was by no means a deus ex machina but rather a significant realignment of existing force fields. ${ }^{22}$ More surreptitiously, state or authoritarian violence, especially when it is as well-honed as that of Indonesia's New Order, tends to penetrate and suffuse as a spirit of violence in every space of society from the economy and domestic life to language and consciousness-even after it is gone. ${ }^{23}$

In what follows, I pursue, as closely as possible, in the minutiae and momentum of Maluku's conflict, but with a special focus on Ambon, the dynamics, modalities, and material technologies through which violence proliferates and becomes sedimented. The radical refiguration over time of what was previously considered possible, expected, or so taken for granted as to go unremarked and the concomitant breakdown of trust in what everyday life has to offer-especially the visible appearances through which it is conventionally known-describes the particular kind of violence at issue here. At the same time, I heed Mary Steedly's call not only to localize violence-something that much work on violence in Indonesia does a very good job of-but to keep "the landscape of the banal in view." 24 To the crucial temporality of the "things that don't fall apart" and "the ordinary routines of everyday life ... when expectations hold," I would add the way in which the banal is itself rearranged by violence as the investment and trust in everyday appearances wane and the taken-for-granted shape of things - foremost that of selves and others - and the circumstances in which these ordinarily present themselves shift and morph in often highly disturbing and startling ways. ${ }^{25}$ In so doing, I pay special attention to those things to which many Ambonese were themselves most attuned in these unusual, horrific times, including the changes in the city around them and their relation to it.

Already in the early days of the conflict, barricades sprung up in Ambon's streets, inhabitants set up command posts at the edges of neighborhoods, bullet-scarred surfaces began to replace the shiny facades of fish restaurants, coffeehouses, and gold jewelry and souvenir shops that had once lined the city's main arteries, now increasingly littered with the debris of battle and garbage that often remained uncollected. In the wake of the destruction of Ambon's main market at the onset of the war, smaller, religiously segregated markets 
emerged in its stead, obstructing sidewalks and cluttering streets, while the itinerant vendors of chicken satay, yellow rice, and hot tea began to sell articles previously available only in the city's shopping mall and fancier stores, like clothing (Figure 4) ${ }^{26}$ For most of its inhabitants, the space of the city shrank as it became zoned and they were increasingly confined to one or another of its religiously marked territories. At the same time, the city was unmoored in unprecedented ways. Much of its population was on the move, beginning with the forced exodus of the derogatively named BBM (short for Buginese, Butonese, and Makassarese or Muslim migrants) ${ }^{27}$ in the first days of the war and the multiple displacements occasioned by the fighting-the destruction and torching of homes and buildings, and refugees fleeing from one part of the city to another, as well as into and out of Ambon-through the emergence of what one priest dubbed new "categories of mobility." 28 The latter comprised, for instance, pedicab drivers and easily mobile others who, as the war dragged on and the city became increasingly divided, began to traffic between the different sides of the conflict, supplying Muslims with, among other things, vegetables from the city's traditionally Christian hills and Christians with fish from the largely Muslim-controlled coastal areas. Relevant, too, are the motorbike-taxi drivers whose numbers increased exponentially in the early to mid-20oos, since they could more easily navigate the challenging segregated space of the city than minibuses or cars. As the population of Ambon dwindled from a prewar count of around three hundred thousand to almost half of that, all kinds of new people arrived to the city, from battalions dispatched by Jakarta to quell the violence, to the influx of journalists and other media practitioners, humanitarian workers, and reconciliation experts but, as mentioned earlier, also some two thousand jihadis from Java a good year after the conflict began. All of these changes, along with the presence of ruins, the new obstacles and divisions in city streets, not to mention the conflict itself and its many ramifications, radically shaped and continued to reshape the appearances that had hitherto made Ambon what it was. Over time, the city became an increasingly unfamiliar place for many of its inhabitants, permeated with new and not always easy to determine dangers, as I describe below.

\section{Fire without Smoke}

Let me begin at the beginning-itself a point of bitter contention between Christians and Muslims, since each side accused the other of largely preparing and masterminding the onset of violence. Even though Ambon is located on Indonesia's eastern outskirts, it is hardly an island unto itself, which means that Christians and Muslims there are cognizant of violence elsewhere, especially 


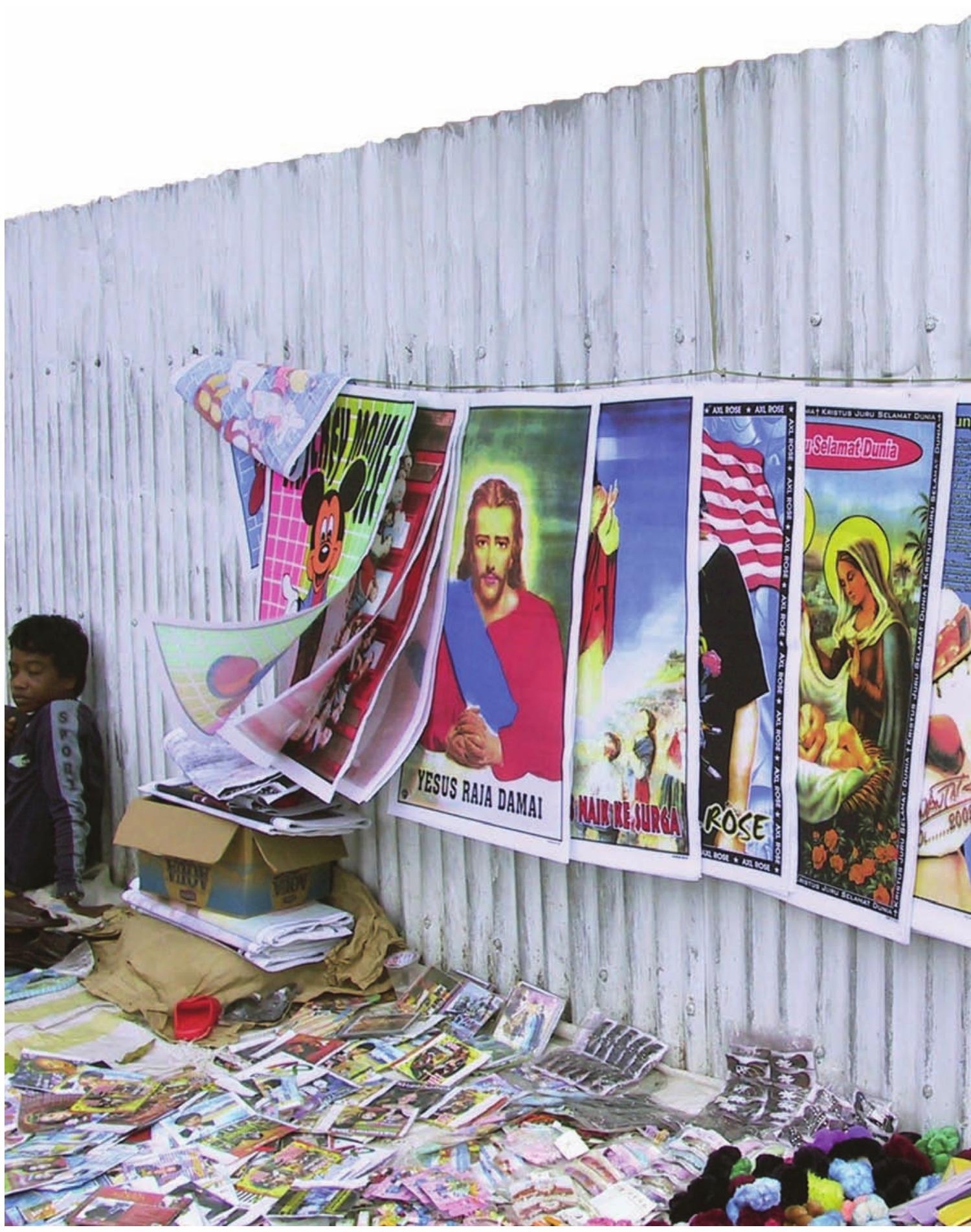

Figure 4. Street market, Ambon, August 2003. Photo by the author. 
when it is religiously inflected. As on Lombok, an island about one thousand miles west of Ambon, where, following an outbreak of anti-Christian riots in early 2000 , graffiti on a house read "This is in response to what was done to Muslims in Ambon," ${ }^{29}$ so, too, may events in other places seize hold of the imaginations of Ambonese, especially those that took place during this time in the nation's capital, Jakarta. Most accounts of the war name a fight between Ambonese gangsters at a gambling den in Jakarta's Ketapang neighborhood in November 1998, the ensuing anti-Christian violence and church burnings following the deaths of four Muslims, and the arrival of more than one hundred uprooted underworld gangsters (I. preman) ${ }^{30}$ to Ambon as the prelude to the city's trouble in January 1999. While evidence that these thugs took to Ambon's streets on January 19 is inconclusive, many Ambonese to this day, both Christian and Muslim, believe that they were sent to the city by "the center" to instigate violence. ${ }^{31}$ Whatever the case, the arrival of this large group of violent men, along with the widespread awareness of the recent brawl implicating them in Jakarta and the overall uncertainty of these times, left at least some people with the impression that something imminent was about to befall their city.

Although this is usually not mentioned in descriptions of Ambon's conflict, in the wake of these events the Malukan governor convened a meeting of community leaders in December 1998. ${ }^{32}$ The governor impressed upon Ambon's Muslim and Christian communities the need to be prepared for violence, to be on the alert, and to guard against provocateurs and rumors. Meant as precautionary, the meeting instilled a sense of the possible in an already nervous city, working as an augury of what might happen before it actually occurred. Besides inaugurating a watchful, anticipatory form of imagination, both sides went home and set up posko, which are either communication or command posts (a slippage that suggests how easily the one slides into the other), with networks of mosques and churches connected by telephones. In the last week of Ramadan, which ended on the day the conflict began, sightings of Jesus in the suburb of Gudang Arang caused thousands of believers to flock to the site for days, frightening Muslims with their displays of emotion. ${ }^{33}$ Throughout the war, such sightings persisted in the city but also elsewhere. For instance, in Pineleng, in the hills above the Christian-majority city of Manado, where many Protestant and Catholic refugees from Maluku had fled and where, in July 2001, crowds gathered in the hope of catching a glimpse of the Jesus face that had surfaced on a chapel wall. ${ }^{34}$ In Ambon, one visionary had committed to canvas his dream of the apocalypse engulfing the Malukan capital as an angry God looked down on the city (see Chapter 4). Dated in large, luminous white letters several days before the conflict began, the depiction of his dream 
prefigured not only the violence but also the figuring momentum of Jesus pictures erupting in the city's war-torn streets. ${ }^{35}$

In the case of Ambon, anticipating and preparing for the worst can in crucial respects be said to have produced the worst. When the fight broke out in the city's main marketplace on January 19, each side quickly mobilized its members-staging in no time at all a battle between forces that were rapidly designated Christian reds and Muslim whites. On either side, representatives claimed that the opposite party appeared in the streets wielding matching machetes, something that was taken as a sure sign of their culpability in initiating the violence. Others pointed to the colored head ties-red for Christians and white for Muslims, allegedly worn by one or the other side from the first day of the confrontation-that betrayed the premeditation of belligerence. Depending on the perspective, either Christians or Muslims would have formed a huge swath of homogenous color reminiscent of the vibrant bands characteristic of political rallies, school parades, and civil servant gatherings in Indonesia. ${ }^{36}$ Ironically, it is precisely this preparedness and visible organization that each side repeatedly held out to the other as proof of their opponent's preconceived plan to mount an attack. It is also what many scholars seized upon as evidence of the conflict's large-scale, coordinated, behind-the-scenes machinations.

My second example of how anticipation augurs what actually comes to pass also derives from that same first, fateful day-one that happened to coincide with Idul Fitri, the festive close of the Muslim fasting month Ramadan. In retrospect, some may see January 19, 1999, as falling into the category of "likely violence days," a formulation coined by a U.S. embassy security officer in Israel in recognition of the patterned repetition of violent outbreaks on Palestinian commemorative occasions. ${ }^{37}$ Whether conjoining identity and trauma or, as with Idul Fitri, religious celebration and community, such days are charged with a practiced, ritualized sense of collectivity. Yet in many parts of Indonesia and in Ambon, until the war, the celebration of Idul Fitri was also crosscut, its alleged communalist potentiality complicated by interreligious conviviality, hospitality, and sharing. Nor was Christmas in Ambon much different in this regard. In 1999, however, the last day of Ramadan saw fights break out among young men in various parts of the archipelago, including four places in Central Java, also in West Java, Central Sulawesi, North Sumatra, the South Sumatran city of Lampung, and West Kalimantan. ${ }^{38}$

"Bloody Idul Fitri," the Muslims' preferred name for the day, yielded "Bloody Christmas" later in the conflict, commemorating the destruction of Ambon's landmark Silo church on December 27, 2000. ${ }^{39}$ In opting for such names, each side aimed to blame the other while claiming victimhood for itself within the 
intense negative reciprocity that, together with anticipation and the countermoves this provoked, was another key dynamic of the war. The reciprocity played itself out in multiple registers - from the back and forth of onslaughts carried out with crude weapons in the conflict's initial phase, in which the brutal actions of one side elicited even more gruesome retaliations by the other, to the colors, names, forms of address, and graffiti through which Muslims and Christians aggressively mirrored and engaged each other.

On that first day, a journalist friend of mine found himself at the office of Ambon's oldest newspaper, Suara Maluku, alternately taking calls from a Muslim friend at home in the neighborhood where the battle subsequently broke out, making plans for the Lebaran celebration that evening, and from a Christian friend with whom he was coordinating their joint attendance at the feast. ${ }^{40} \mathrm{On}$ call from different ends of the city, his ongoing double conversation with his two friends and colleagues is itself an instance of the first stirrings of the conflict. After finalizing their plans, the Muslim friend immediately called back, telling my friend to bring his camera since a fight had broken out-a regular fight, he said, the kind of thing we have seen before. The other friend called again, too, saying he would not come because people were in the streets with machetes, up in arms because of a burned-down church. Caught in between, my friend heard of both mosques and churches being burned before any smoke was seen in the city. As he himself put it, the rumor preceded the event and, contrary to the laws of nature, where there was fire, no smoke had been seen. Indeed, the only fire around was a wildfire of misinformation and suspicion sweeping with incredible speed across Ambon.

Any kind of balanced information, not surprisingly, was one of the first victims of the violence. Soon after the conflict broke out, the three friends and Suara Maluku journalists who happened to be Muslim, Catholic, and GPM Protestant, and who had conversed by phone across the city as the violence began, could no longer come together. The location of the paper's office in what rapidly became marked as Christian territory meant that Muslim journalists could not safely come to work, while Christians dared not venture into the Muslim area where the newspaper's printing press was now located. Seizing a good business opportunity when it emerged, the Surabaya-based media conglomerate the Jawa Pos group, of which Suara Maluku was a member, created a Muslim spin-off newspaper, the Ambon Ekspres, where the former Muslim Suara Maluku journalists were employed. With the increasing severity of the conflict and the rise in partisan feelings, this situation further aggravated the rapid polarization of local media-not just print but, as we will see, the vernacular forms that especially predominated in the conflict, like graffiti, VCDs, and 
incendiary pamphlets or "hardcopy rumors" - into Christian and Muslim mouthpieces, thereby glossing over the heterogeneity within each religious camp. ${ }^{41}$

A strict chronological account would fail to do justice to the erratic rhythms and unfoldings of the war, which depended as much on fantasy and desire as on apprehension and fear. If experience, contrary to popular belief, is mostly imagination in any circumstance, this is all the more so in the fraught mobile environment of war, where the tendency to make things seem grotesque and larger than they really are is enhanced, as Clausewitz already recognized in the nineteenth century. ${ }^{42}$ In much of the scholarship on Ambon, too little attention is given to "the work of the imagination" and the construction of knowledge in violence's production and sedimentation and, specifically, how these compel and propel particular actions and shape those who carry them out. ${ }^{43}$ The mobile, dense, and murky terrain in which something that is waiting to happen does in fact happen is built on spirals of information, misinformation, and disinformation, on the revamping of criteria of credibility, customs of trust and accountability, and on knowledge forms that blur the boundaries between what is seen and what is heard, what is known and what is suspected, what is feared and what is fantasized, what is fact and what is fiction. Rather than try to extricate a causal chain, I argue that confounding any clear trajectory from which one might plot the actions of the various parties involved is a swirl of images, vocabularies, sound bites, slogans, and vectors introducing a host of mediated and mediatized elsewheres into the picture-or, inversely, projecting Ambon, with all its troubles and sufferings, onto a larger-than-local scale. It is in the thick of such things and their powerful effects that one may begin to address Ambon's violence. ${ }^{44}$

This means situating violence in all its complex specificity at the myriad sites of its production as a structuring and destructuring force of social life. It is there where violence emerges and spawns its own supplementary effects, which, in turn, are evidenced by new outbreaks of violence in other parts of the city, across Ambon Island, or elsewhere in Maluku. ${ }^{45}$

\section{The Thick of Things}

Let us turn now to the myriad images, vocabulary, anticipatory practices, elusive agencies, and specters, and to the consolidation of hard-edged religiously inflected enmity that characterized the war. This means seriously engaging the thick of things that, for many Ambonese and others implicated in the violence, was part of its defining conditions. It was in these conditions, too, that the protagonists came to see and, significantly, not see each other within the 
aggravated perception that over time came to describe an important dynamic of the war.

Take the difference between the Christian reds and the Muslim whites. Despite the common perception that these groups stood opposed from that first day as ready-made enemies, this is hardly the case. Notwithstanding the serious grievances, suspicion, and intense competition between religiously embedded networks ${ }^{46}$ and insidious stereotypes that marked the relation on both sides, many of those who clashed in Ambon's streets were also in an important, hardly negligible sense neighbors. Whether one understands such relationship in terms of poor knowledge of the other, the "alien but proximate" space inhabited by culturally and socially different "strangers" in another depiction of one of Ambon's crowded, religiously mixed, urban neighborhoods harboring many poor migrants, or intimate, as in my own preferred description of the religiously based enmity that subsequently evolved between Christians and Muslims, the more pertinent issue is not the factual knowledge held on one side or the other ${ }^{47}$ It is rather that the large majority of Ambonese, both Christian and Muslim, assumed with no uncertainty that they knew their long-standing religiously distinct neighbor. To be sure, the intensely populated conditions in Ambon City proper where Muslims and Christians lived cheek by jowl, including the dense proximity of more religiously homogeneous neighborhoods, are relevant to this understanding. But beyond any empirical reality, the assumption of long-standing familiarity and knowledge of the other was what really came to matter in the messy terrain of the war (see also Chapter 4).

The cruel work of severing what was once the largely livable city of Ambon for many of its inhabitants and the congealing of difference into hardened binary identities resonates with instances of so-called communal forms of conflict elsewhere, where-much as in the Malukan capital-ordinary people had for a long time tacitly agreed to live together with all their differences and, therefore, also with greater or lesser degrees of communal tension and occasional, small-scale violence. This is a somewhat different perspective than the anodyne one offered by then president B. J. Habibie, who lamented in November 1998 that the religiously inflected brawls involving Ambonese in Jakarta shattered the long-standing reputation of Ambon as a model of religious tolerance in Indonesia. However one describes this kind of cohabitation, once enmity is sealed in bloodshed and memory and codified through collective talk and imagery, ordinary people can apparently engage in and commit the most horrific acts, and dehumanization of the opposing party can become second nature for just about anyone-over time. ${ }^{48}$ Contrary to easy discussions of "dehumanization" (as if it involves something that people wake up to one 
day and decide to do), the distancing that dehumanization presumes must actually be produced, with an enemy made and identities recognized and reforged in the heat of impending and ongoing confrontation. What it means to be human and, therefore too, nonhuman will also be inflected by attitudes toward killing, suffering, and the body, as well as by notions of vengeance, retribution, and reconciliation, among many other things. ${ }^{49}$

I do believe that the extreme violence in Ambon was, at least in part, attributable to the need to turn those in one's own image into something else, with the violence figuring as part of the work involved to bring about a radical difference..$^{50}$ For all the underlying tensions, interreligious rivalry, dark legacies of the Suharto era, and even turf wars between the military and police, the civil war in Ambon was just that: largely fought out among Ambonese-that is, among former colleagues, friends, and neighbors. A refugee from the area even suggested that the differently colored head ties worn from the beginning on both sides were imperative for telling each other apart-given, he said, that we are all Ambonese. ${ }^{51}$ One might even venture that in this example, the work of appearance was superficial, operating solely at the level of outward appearance-that is, with the difference between Christian and Muslim imposed externally by Ambonese who found it difficult to discern friend from foe. Over time, however, as the violence persisted, a different discourse became increasingly prevalent. Following this discourse, religious difference increasingly came to be seen as naturally embodied and, as such, identifiable by physical appearance alone, which was understood to operate independently of externally imposed signs like head ties or other cultural accoutrements.

Already early on, however, distinctive colors and other distinguishing marks seemed unable to sufficiently conjure difference out of taken-for-granted sameness or to contain the weight of growing fear and hatred as the experience of war, with its trail of anger, loss, and grief, increasingly shaped the terms of perception and action on either side. Perhaps hatred is precisely such a restless search for new names and new labels in which to provisionally shelter an emotion that inevitably exceeds them, or perhaps such a search is simply part of the effort that goes into consolidating a radical, hard-edged rift between those who previously-notwithstanding all their differences-lived in some sense together as a workable urban collectivity. Whatever the case, additional names and images of the enemy Other accreted along the way, further deepening the divide between Muslims and Christians and making it more difficult to imagine its undoing. A by-now-infamous public service announcement broadcast on national television and on several commercial channels some months after the violence began seems to have been compelling enough to emerge as an emblem of mutual enmity. Shortly after its airing, the spot took on a life of its 
own-one quite different from that intended by its producer, who, as a result, claims to have suffered trauma.

A sweet, sentimentalized vignette of only several minutes, "Voice of the Heart-Acang and Obet" features two young Ambonese boys, the Muslim Acang, short for Hassan, and his bosom friend, the Christian Robert, or Obet. ${ }^{52}$ The scene is an abandoned, gutted-out basement of a large, concrete building, evoking the ravages and dislocations of war. The spot opens with Acang awaiting his friend, anticipation on his face, and the smiles and joy on both sides when Obet arrives (Figure 5). The two share a quick, stolen conversation in which the more obvious problems afflicting Ambon's children somewhat stiffly parade by: Obet complains we cannot go to school, see our friends, study at home, or sleep; Acang, that he misses school since moving to a refugee camp, where life is difficult. To Acang's question "Why did Ambon fall apart like this?" Obet responds, "I don't know, it's a problem of adults." Acang is left with the punch line: "It's an adult problem and we kids are the victims." The camera zooms in on the two friends, their arms around each other, speaking jointly from the heart, the one echoing the other, voicing the hope and mutual promise

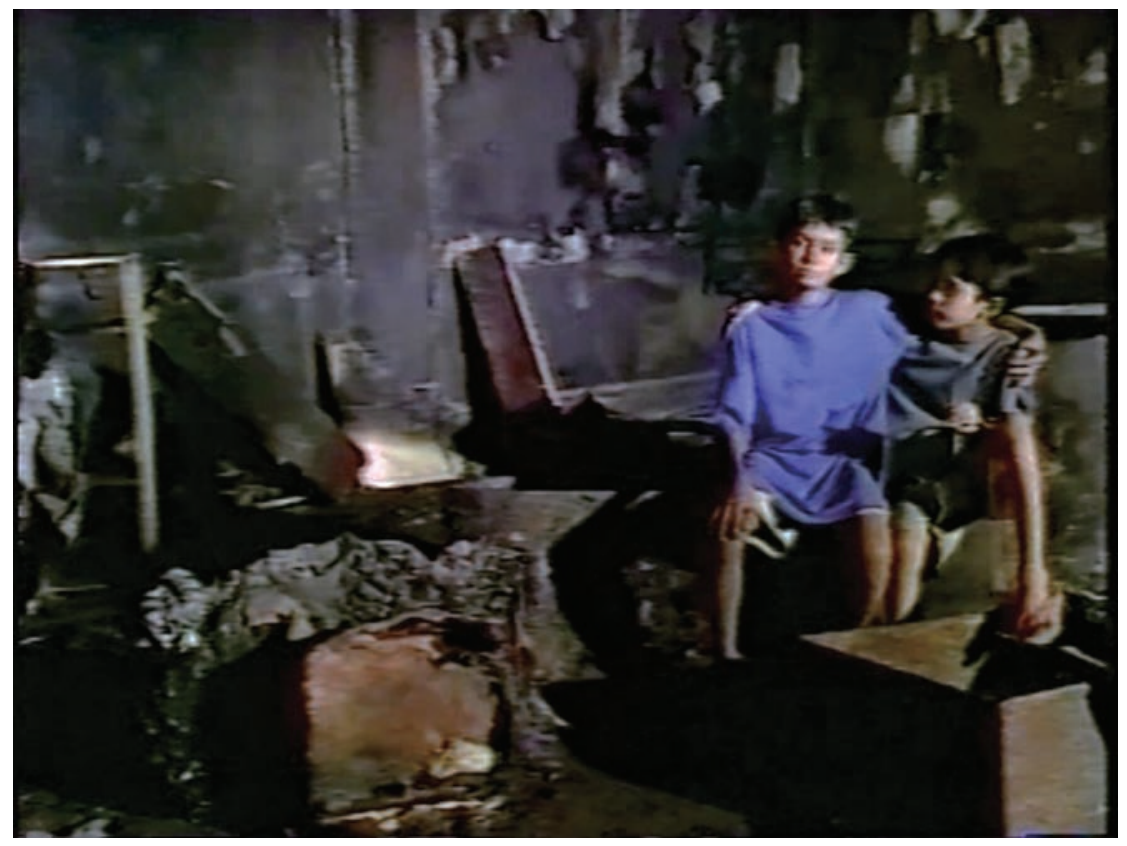

Figure 5. Screenshot from the video CD "Voice of the Heart-Acang and Obet." Produced by Franky Sahilatua, 2001. 
that "even if Ambon is destroyed like this, our bond of brotherhood should not be broken."

The spot has all the trappings of the documentary-sophisticated, objectivist aesthetics and a credible backdrop bolstering cinema's illusory realism, ${ }^{54}$ authentic Ambonese dialect, Indonesian subtitles, and two emblematic, young Ambonese boys. The drama resurrects the trope of friends torn apart by uncontrollable circumstances-seen on-screen as early as D. W. Griffith's 1915 classic The Birth of a Nation, set during America's Civil War, but also more recently with the Indonesian Revolution as backdrop in the film version of the 1948 Dutch novel Oeroeg by the grande dame of Indies literature, Hella Haasse. Strikingly though, unlike their predecessors - whether standing in for America's North and South or for the Netherlands and the birth of Indonesia-the Ambonese heroes of "Voice of the Heart" do not grow up. It is worth pointing out, incidentally, that the theme of a nation divided not only underwrote the "Voice of the Heart" PSA but was often read into the rupture between red and white in Ambon's war as allegedly corresponding to the two horizontal bands of the "red and white" (I. merah-putih) Indonesian flag. In the immediate postwar period, the popular genre of reconciliation art and media focused on children's faces, voices, and drawings also uncannily reiterates the bifurcated symmetry of both the PSA and the Indonesian flag, something I discuss in Chapter 5. Yet, notwithstanding its compelling aesthetics, the trope of bosom friends, and the PSA's message of peace, the names Acang and Obet came to be shorthand for enmity for each side in the conflict.

To be sure, children are the future of any nation and emphatically so in Indonesia, where a large proportion of the population is under the age of twenty-five..$^{55}$ The war in Ambon had terrible effects on everyone-not least the children, many of whom were left fatherless, orphaned, homeless, in refugee camps, and out of school. ${ }^{56}$ Many saw and experienced horrific things and many, too, participated in their making, serving as militia messengers on both sides, becoming skilled producers of crude, deadly weapons, torching houses, and vandalizing neighborhoods after an attack. One source claims that between two thousand and four thousand children aged seven to twelve-the same age as Acang and Obet-took part in raids on enemy villages or assisted in defending their own. On the Christian side they were known as "sandfly troops," among Muslims, "crowbar troops." 57

Apart from their involvement in the conflict, children featured prominently on the online site of the Protestant newsgroup Masariku and on the website of the Communications Forum of the Sunna and the Community of the Prophet (I. Forum Komunikasi Ahlussunnah wal-Jama'ah, or FKAWJ), of which the Laskar Jihad was the paramilitary wing..$^{58}$ On both sides, the appeal and 
propaganda value of children-also the point of departure for the Acang and Obet ad-was deployed to portray children as both victims and key agents in the war. ${ }^{59}$ Books with a jihad theme targeted children, while the FKAWJ website produced reports on the "DIY Troops" and "Plastic Troops," the latter evocative perhaps of toy soldiers, or their terms for Malukan children who dressed as jihadists and aimed to partake in their struggle. ${ }^{60}$ Masariku, in turn, in its Portraits of Maluku series, showcased photographs of child members of the sandfly troops in uniform, wielding wooden swords with miniature bibles hanging from their necks or protruding out of their pockets. ${ }^{61}$ In short, while the Acang and Obet ad aimed to promote peace rather than generate sympathy for either of the warring parties, the hijacking from the ad of the boys' names to serve as key terms of enmity suggests that what mattered most was the connection between violence and the figure of the child characteristic of the genre-a connection that, as here, can be mobilized for quite different ends.

As opposed to the more belligerent depictions, what fantasy structures the pro-peace PSA "Voice of the Heart"? It is a fantasy that at the time also underwrote letters and poems of refugee children published in Indonesian newspapers that similarly emphasized the longings for each other among former Christian and Muslim playmates. ${ }^{62}$ To set off the pair from the violence around them, Acang and Obet's cave-like shelter is a microcosm where, speaking from their child hearts, the pair evokes the pela blood brotherhood alliances mythologized in Maluku and frequently held up in peace and reconciliation initiatives as a model of harmonious religious plurality and coexistence (see Chapter 5). These alliances conjoin some Central Malukan Christian and Muslim villages but also some Christian villages through bonds of kinship and mutual aid that are stereotypically evoked in the image of Muslims building the church of their Christian pela partners or Christians aiding their Muslim brothers in constructing or repairing a mosque. If these blood-brother relations were already widely acclaimed examples of cross-religious relationality before the war, it was only in its context that the bond developed into an instrument of Christian and Muslim reconciliation and peace generally. As such, the ad offers not only an early intimation of its later importance but also the degree to which the alliances have been romanticized. ${ }^{63}$ The space where the two friends meet is also a haven of apolitical innocence-located less beyond the upheavals of dislocation, refugee status, interrupted schooling, and everyday trouble, which the ad clearly names, than beyond the politics, power structures, and political economy permeating and informing all of these. The diminutive child's world also serves to diminish the conflict-bringing it down to size, to that of spokenfrom-the-heart childhood honesty and clairvoyance-and thereby trivializes its real impact on Ambonese children. At the same time, the PSA's exaggeration 
of interiority-its portrayal of a miniaturized world of children, the voices of the two friends issuing directly from their hearts, and the secluded surroundings in which the meeting between Acang and Obet occurs-enhances the ideological impact of the message it hopes to convey. ${ }^{64}$ The spot offers a fantastic world unto itself, one that makes the exacting, difficult circumstances of wartime absolutely exterior to itself, presenting a time out of time that negates change and the lived reality of the war. ${ }^{65}$

In blaming adults for Ambon's violence, the spot also conjures an orphaned landscape via a double delegitimization: of the parents of all Obets and all Acangs, of pemuda-or "youth," a morally charged category on the crest of all revolutionary change in Indonesia, recently reinvigorated during Reformasi-of students, and of all others excluded from the enclosed world of "Voice of the Heart." ${ }^{\prime 66}$ Like Viva Indonesia! An Anthology of Letters to God, discussed in the Introduction, and other child-centered productions of the time that launched children's faces and voices as sentimental antidotes to violence, the ad unambiguously declares violence an adult problem and the result of their agency. Other productions similarly named or portrayed the abandonment by Indonesians of their duties as parent-citizens, the violent disruption of the father-child bond, or, more abstractly, children who appear alone in orphaned landscapes of one kind or another. ${ }^{67}$ In the case of "Voice of the Heart," what remained after this pernicious erasure was an abstract, easily appropriable clarity-a schema amenable to multiple ends, including violence.

A name and face for the enemy is all that Ambonese took from the spot meant to foster peace among them. Refugee talk on my tapes from 2000 and 2001 is replete with phrases like "Acang attacked," "Obet's territory," "Acang retreated," and "Obet retreated," testifying to the currency of the public service announcement's unforeseen afterlife, the rampant circulation and uptake of media, especially pronounced in such overheated circumstances as Ambon's conflict, and the unpredictability of audience reaction. As late as September 2003, the names hijacked from the PSA could still be heard in Ambon-cautiously if talking about the recent opponent but also exuberantly in peace songs and propaganda. For instance, a drum inscribed with the names Acang and Obet hung in the office of the Jesuit Refugee Service that organized reconciliation events for children.

If, arriving unwittingly from elsewhere, Acang and Obet's message went awry in its adjustment to Ambon's belligerent conditions, so, inversely, did Ambonese actively borrow examples from other places that seemed to approximate their own fraught world. Like a voracious fire consuming anything in its path, everything became swept up and recast in the conflict's polarized terms. Although I cannot date its emergence, the city's main dividing line between its 
Muslim and Christian parts was known colloquially as the "Gaza Strip" (I. Jalur $\mathrm{Gaza}$ ), although several others emerged over time. This name had already been prepared in the first days of the conflict, when graffiti desecrating walls and buildings included insults of Jesus and the Prophet Mohammed, references to Jews, Israel, Muslim Power, and Muslim Pigs, stars of David, and allahu akbar in Arabic writing. Along similar lines, when the Laskar Jihad arrived in Ambon, its members quickly set about renaming streets and tagging guardhouse walls, clinics, and other buildings with the organization's logo, calligraphy, and characteristic images in the Muslim-dominated areas of the provincial capital. ${ }^{68}$ In this way, for instance, Ambon acquired a Martyr's Street that it had never had before. Such fragmentary, free-floating bits of discourse work best in display mode-on T-shirts, banners, posters, and head ties-as visual and verbal slogans. Taken out of context, they also transcend it, becoming monumental and indexing a universe-one of closed ideological systems and stand-off positions. ${ }^{69}$

\section{Soundtracks of War}

Language was another frequent casualty of the war as names like Acang and Obet became codified, venomous accusations and everyday communication was highly politicized-to an extent that accords with the claim of some scholars that in circumstances like that of Ambon, language, along with much else that comprises the everyday, becomes inflected by violence. Violence's effects can be so dramatic that what remains in its wake is merely "the debris of language. ${ }^{\prime 70}$ In the Introduction, I proposed that the present of a city at war may become alienated from the images or language through which it was previously known. ${ }^{71}$ A compulsion to label usurps the place of everyday conversation and exchange, one that in Ambon gave way to a belligerent religiously inspired call-and-response-the Christian cry of "Halleluyah," for instance, countering the Muslim "Allahu akbar" in Ambon's streets, along with numerous other examples of nefarious mutual mimesis. ${ }^{72}$ The aggressive mutual engagement of the opponents left a long-lasting legacy in the Malukan city; for instance, in the Christian convention, dating from the war, of using syalom as a greeting "since the Muslims have wassalamu alaikum," or in the need, when addressing a young Ambonese, to quickly determine whether he is a Muslim bang (from abang) or a Christian bung or she is a Muslim cece or a Christian usi and to use the appropriate gendered and religiously marked terms of address. ${ }^{73}$ Such examples of language's extreme reification may be especially suited to capture the traumatized concretism of the aggravated situation of danger corresponding to the experience of war. ${ }^{74}$ As an attempt by people to visually and linguistically 
get a hold on the increasingly elusive realities around them, reification surfaces as a corollary and symptom of the atmosphere and uncertainty that wrapped the city in war's fog.

Not only language but also sounds were another potent ingredient on the urban battlefield: Muslim VCDs came with nasyid songs that make explicit use of religious dogma and were especially composed for jihad in Maluku, while Christians sung hymns like "Onward Christian Soldier" as they moved toward combat. ${ }^{75}$ Not surprisingly, such soundtracks of war had important effects on those who heard them, instilling courage and a sense of collective purpose before battle and anger and hostility in those on the opposing side. "Us Christians still have the fear of God in us," a young Malukan in Manado told me. "We are diligent churchgoers, now all the more so, more determined. When there is violence, we sing Onward Christian Soldier, onward. When we hear this sung, we feel courageous, and when we go off to battle, we pray first, either in church or at home. We don't want to kill but are forced to do so. If we don't kill, we will be killed ourselves. That is the situation." ${ }^{76}$ By the same token, such singing often instilled fear in Muslims. "Smoke was everywhere, so we were confused," a Muslim woman who had fled Ambon early on in the conflict told me as she described how she saw fires burning everywhere on the first day of violence. ${ }^{77}$ "This is so sad, fires while it is Lebaran. It's a holiday while houses are burning" was how she recalled her thoughts at the time. Two days later, she remembered how "kids between the ages of fifteen and twenty, bare-chested with red ties around their heads" showed up near her home. ${ }^{78}$ "At the time, I could not read the situation, but they were lined up and began to sing. They were singing and yelling and yelling like I don't know what." I asked if they sang religious songs and she replied, "No, those are slow, but these were kind of different. They were singing and taunting the soldiers." ${ }^{\text {" }} 9$ Such aggressive cries and songs could have an effect even on those who aimed to maintain distance vis-à-vis the conflict. A Muslim journalist representing a national news magazine, whom I met in Manado, confessed that while he did his utmost to remain neutral as a reporter, he was so concerned that "one more cry of 'Halleluyah" "would bias his reporting that he asked to be transferred back to Jakarta. ${ }^{80}$ Similarly, a priest complained to me of the effects on Protestants who would tune in to the Laskar Jihad radio station and become revved up by what they heard.$^{81}$ Since the station dominated the airwaves, it was often impossible to drown out, so the incessant insults and provocations of the jihadists continued to infiltrate the walkie-talkies of clergy and others around the city. Much better equipped and more technically savvy than their opponents, the Laskar Jihad included a download section on the organization's website with sound files of such memorable events as the speech given by their founder, Ja'far Umar 
Thalib, at the mass meeting held at Jakarta's Senayan Stadium in April 2000, the event that led to the jihadists leaving for Ambon a month later. ${ }^{82}$ There were also the myriad sounds of wartime communication-from passwords and rapping on utility poles meant to convey secret information to those in one's camp, to the explosions and sounds of different weapons going off and the noise of confrontation and attack. Loudspeaker technology deployed on both sides meant that the sounds of the Muslim call to prayer and imam's khutbah competed with Christian sermons broadcast beyond church walls as congregations gathered up to three times a day at the height of the war. Over time, the aggressive back-and-forth and mirrored vocabularies and practices of Ambon's intimate enemies, emergent out of their ongoing negative exchange, further sedimented violence in the city and, with it, a projection of the conflict's alleged intractability emblematized by its own Gaza Strip(s).

\section{Amplifications}

I am interested in this usurpation of a powerful name from elsewhere because of its effects within the dynamics of the conflict-both more than local and less than global, though feeding off of and beholden to much larger than national designs - and because of the mediatized, mediated realities of Ambon, as virtualized as almost anywhere these days, especially since the war. Akin to the synchronic nomenclature identified by Benedict Anderson with the beginnings of the imagination of community as nation-like New York, New London, Nuevo León, Nieuw Amsterdam-Ambon's Gaza Strip could “arise historically only when substantial groups of people were in a position to think of themselves as living lives parallel to those of other substantial groups of people-if never meeting yet certainly proceeding along the same trajectory." 83 In our own highly globalized times, however, such neat parallelisms between metropole and colony have increasingly opened out, giving way to multifaceted and more rhizomatic forms of imagining. ${ }^{84}$ Thus, the potent trope of the Gaza Strip not only assumed definitive power in Ambon but also insistently cropped up elsewhere-even in what seems such an unlikely place as Venezuela-to characterize what appear to be the most hardened and intractable of violent situations. Another factor that fed into the analogy in Ambon was the locally prevalent assumption that the conflict between Israel and Palestine should be interpreted in religious terms. The specifically Pentecostal understanding that the apocalypse presumes the habitation by Jews in the biblical homeland prior to the Christian end-time further supports this interpretation. Given the importance that charismatic churches assumed during the war, it is safe to conclude that this understanding was also at work here. 
Twinning Ambon with this other, more famous, intensely mediatized wartorn place may have been one way of making the violence in Maluku-hardly a priority in Jakarta-matter, a way of lending local suffering and loss a largerthan-local meaning. ${ }^{85}$ It also demonstrates the theatricality and dramatic imagining of social actors in a world dominated by NGOs, international peacekeeping initiatives, Human Rights Watchers, and other important audiences. If the sense of audience is always crucial to the production of political violence, ${ }^{86}$ in Ambon's conflict different senses of audience may be discerned that draw on identification and desire for recognition across vast distances, build on histories of connection (or presumed connection), and were facilitated by changes in communication and media technology and, not the least, imagination. In an admittedly oversimplified fashion, there is the immediate sense in which Christians and Muslims in Ambon were significant audiences for each other, something that I have repeatedly emphasized. But there was also the widespread perception, or at least hope, that important international actors held to be potential supporters might be watching as well-such as, for Christians, the United Nations or European Union, and for Muslims, their fellow coreligionists around the country but also in Southeast Asia and the Middle East. Another crucial ongoing dimension of the sense of audience for Ambonese on both sides of the conflict was the more transitive awareness that others were seeing what they saw. ${ }^{87}$ Necessarily, the ways in which the gaze of such others is imagined varies socially and historically, but it figures increasingly as a dynamic in situations of crisis and conflict everywhere. If during Indonesia's Reformasi people felt that the eyes of the international community witnessed events in the country, ${ }^{88}$ the gaze of others in Ambon was, as so much else, religiously defined, as Muslims and Christians alike imagined and hoped that their transnational coreligionists would not only be watching them but also be watching with them as partisan witnesses and coviewers of the war. And to some extent, they were: Muslims rallied in Jakarta against the alleged Christianization of Maluku or tagged walls in Lombok with graffiti about the burning of a mosque in North Maluku, while Dutch Malukans, the majority of whom are Protestants, maintained close contact with their relatives in Ambon and mobilized in different ways around the conflict.89

Notwithstanding such examples, arguments that foreground the empirical fragmentation across different media of incidents of violence according to the type and location of audience or insist that the "actual participants" of a given "transnational or macropublic sphere" may in fact only constitute a "numerically small group" miss the point..$^{90}$ While useful perhaps for purposes of market research, such analyses bypass the role of imagination in the amplification of war's import-including the imagination of others who see what you 
see, as suggested here-but also, how, as with any other public, religious publics are never wholly present to themselves. ${ }^{91}$ In any event, one wonders if the import of the conflict, once amplified, can thereafter so easily be scaled down. For once you imagine Ambon as "Gaza," or a stage for an epic contest of Christianity and Islam, how do you get back to some version of a messy, if more or less workable, cohabitation? Besides the enormous difficulties of moving on and reassembling lives after conflict, due, among other factors, to how its violence lingers in the patterns, language, and gestures of everyday social existence, much of war's materiality may long remain in place. It has certainly done so in Maluku, in myriad ways, ${ }^{92}$ not least via the spectacular assertions of aggression and exclusion performed by Ambon's Christ pictures vis-à-vis Muslims. For let us not forget that these adamantly Christian productions continued to be maintained and repainted for a good decade after the official peace. An example from the conflict in North Maluku are the martyrs' graves and other monuments that, while offering a material counter to an official discourse on "reconciliation," repressive of memory of the violence, run the risk of objectifying the volatile religious terms in which the conflict was played out as they also bear witness to the trauma and dead of war. ${ }^{93}$ Like the VCD showing a Christian mural where the camera zooms in on Jesus holding a globe on which the state of Israel has grown to continental size, such literal amplifications were also part of the conflict's aggravated stakes and the wider enhancement of its significance. $^{94}$

Neat schema and ideologically compelling images, like those from "Voice of the Heart," Ambon's Gaza Strip, or insults sprayed on city walls, facilitated amplification since they summed up so much in succinct condensations of abstraction and affect that could circulate and be remediated easily. Within a much larger arena of conflicting messages, fragmentary information, and representational immediacy, amounting to a veritable infrastructure of the imagination, some stood out more than others, proving provocative enough to trigger large-scale violence. One especially infamous incident involved a phantom letter allegedly issued by Ambon's GPM church calling for Maluku’s Christianization. Once multiplied, read aloud over megaphones, and spread about, this letter contributed directly to the dislocation and deaths of numerous North Malukans. ${ }^{95}$ While Muslims seemed to have accepted its veracity without question, Christians indulged in forensics that exposed the letter's falsity: "bizarre and mysterious, the leaflet lacking a letter head and using a language that is not that of the church only circulated among Muslims," one report notes. ${ }^{96}$ Such dark circuits underlaid, crossed, and competed for attention with partisan descriptions by the local press (the Suara Maluku newspaper, as noted above, not only consolidating into a Christian paper but spawning a Muslim 
competitor), village gossip presented as truth on Christian and Muslim websites, Christian-inclined state radio vying with the illegal Laskar Jihad station, banners spanning avenues or hanging from buildings, rumor piggybacking on technological reproducibility to produce "xeroxlore" in folklorists' terms, ${ }^{97}$ graffiti sprayed on walls, streets, and war-damaged buildings, and numerous processions and protests that occupied the main thoroughfares of the city. These included mass ambulatory prayer sessions as Christians took to the streets with red head ties, bibles in hand, and pictures of Christ that floated above the crowd. Muslims, in turn, wore white head ties, unfurled green and white flags, and bore banners with Arabic calligraphy. Local representatives of the national organization of Concerned Women, a procession of Christian clergy in February 2001, including Ambon's bishop and former bishop, priests, brothers, and nuns, and numerous Protestant ministers representing different denominations protested against the forced conversion of Christians by jihadists on the Malukan islands of Kesui and Teor in late 2000 and early 2001. Demonstrations by Muslim refugees objecting to the ban of the jihadist radio station, or others protesting the imposition of civil emergency, were among the many public manifestations of the city at war. ${ }^{98}$ These divergent and convergent voices and views drowned out, echoed, interrupted, and jostled each other in the cramped, ideologized, divided space of Ambon, made up of myriad mediated elsewheres, amplified, narrowcast, obscure, and confusing realities.

Even the supposedly, on the face of it, simple problem of actors-the whodunit of the violence-could be hard to pin down. Take the abstract lexicon produced by some nonpartisan, pro-peace press journalists-people with the very best of intentions. In the aim of diminishing the conflict, they often deliberately obfuscated the information about a violent exchange. ${ }^{99}$ In part, this may be a legacy of the self-censorship and prohibition under Suharto on SARA-or "Suku, Agama, Ras, Antar-Golongan," publicizing differences based on tribe, religion, race, and class - that remained operative in many quarters during the Reformasi era, notwithstanding its call for transparency and a new openness. But it also had to do with the way in which peace journalism, only recently introduced in Indonesia at the time, was often interpreted. Reading the accounts of some journalists, one is left none the wiser: houses of worship are stripped of denomination, and only elusive actors are named- "certain parties," unidentified "political elite," "puppeteers," and the ever-popular "provocateur."100 Applied, in short, was a systematic unnaming of the war's combatants. ${ }^{101}$ Whatever its aim, I argue elsewhere that this lack of specificity with regard to agency may in fact produce a sense of phantom danger, lurking both nowhere in particular and therefore potentially everywhere in general, provoking fear and, perhaps, new violence. ${ }^{102}$ Moreover, with the use of phrases like "Muslim 
cleansing," imported early on from Jakarta, and other vivid, slanted versions of war, a more neutral source is quickly marginalized since-as one Ambonese journalist put it-it appears ludicrous by contrast. ${ }^{103}$ I further discuss some of the dilemmas that reporting on the conflict posed for journalists in Chapter 5.

\section{Anticipatory Practices}

Throughout this chapter, I have stressed the role of the possible and the conditional in the spread and sedimentation of violence. It remains to give some sense of what people caught in the midst do-with multiple influences and images impinging upon them. Let me begin with the VCDs made by both Christians and Muslims but circulated only by the latter (which I therefore highlight). At first glance, they fly in the face of the stripped-down media reports, sound bites, and schematic images discussed above. The VCDs' appeal depends upon their sympathetic, almost tactile engagement with, especially, victims and their bodies-on close-ups of oozing wounds, bullets protruding from body parts, maimed and charred corpses, and the bodily contortions, moans, and screams of people's suffering too painful to watch. But they were watched-over and over again. Besides the victims, the occasional imam, Muslim NGO spokesperson, or, in the case of Christians, Protestant minister delivering an emotionally charged sermon in the ruins of a burned out church, and the hands of surgical intervention (doctors themselves are rarely seen), the main action is that of mass scenes of attack and violence drawn largely from the war's earliest moments. Very much in the thick of things, these VCDs provide little perspective on events and often make no pretension to having a narrative-besides, that is, the insistent, repetitive one of victimization resurrected on and out of body parts. ${ }^{104}$ Indeed, part of the affective appeal of this VCD genre, if necessarily different for Muslims and Christians, may reside precisely in its obsessive return to the "wound" and repetitive enactment of disaster that does not resolve itself easily into narrative but repeatedly assaults the viewer. ${ }^{105}$

These VCDs are composite works; they range from the more professional to the homemade, though both often contain the very same clips, which were clearly shared and copied profusely. In Ambon I was told that, during the war, just as around Indonesia one could commission a CD of favorite songs, so, too, in some of the city's shops, could a compilation of select scenes be put together on a personalized VCD. Some of the clips were produced, or at least endorsed, by the military and feature soldiers casually standing by or going about their business, neither shying away from nor interrupting the camera. Others are said to have been filmed by doctor-volunteers who not only stitched wounds 
but lent their steady hands and surgical gazes to the close-up cinematic engagement of broken bodies. Many VCDs, at any rate, are pieced together, and many evidence the presence of different hands-some steady, others shaky, and still others apparently entranced by the zoom function.

How did the mass appeal of the VCD genre translate into the actual creation of a sense of community and the shaping of perception and action in the conflict? This is a question with inevitably somewhat different answers for Ambon's Christian and Muslim populations, one that I address in more detail elsewhere with regard to Muslims. ${ }^{106}$ If, however, community in the sense of collective purpose and futurity has anything to do with the circulation and consolidation of shared symbols, memories, and sentiments, then the nature of their mode of transfer and sedimentation is clearly important. Among Christians in Ambon, VCD traffic was relatively small scale, difficult to break into, and closely controlled, with VCDs bearing advisory labels like "intended for own group." Similarly, the founders of the Christian website Masariku expressed their concern that materials from the site might fall into the wrong hands, and they repeatedly warned their members that circulation should only take place within the Masariku group. ${ }^{107}$ Such concerns evidence the sense shared by many of Ambon's Christians that they were a tiny minority under continual threat of attack or even annihilation by an aggressive Muslim majority. For even if Protestants received support from their relatives in the Netherlands and via church networks there, around Indonesia, and to some extent internationally, they had difficulty collaborating, probably due to the number of denominations in the region and the divisiveness among them. This may have further enhanced their paranoia and insistence on group loyalty. By contrast, the Muslim VCDs were not only mass-produced, sold during the conflict in markets and streets across Indonesia, but transnationally popular and quite homogeneous: Ambon's VCDs looked much like Kashmir's, Bosnia's, and those of Palestine watched in Malaysia and elsewhere. ${ }^{108}$ Once the Laskar Jihad began to arrive in Ambon in May 2000, its members trafficked openly in jihad VCDs and print media on the large passenger boats heading to Maluku from the western parts of the archipelago. Their newsletters also explicitly located Ambon's conflict within a larger, transnational arena of religious warfare by referring, for instance, to religious war in Bosnia. ${ }^{109}$

For any of these VCDs to have any effect-whether in the claustrophobic enclave of Ambon's Christians or in the transnational Muslim space stretched thinly perhaps across the geopolitical mosaic of different Islams-a number of things are needed. The first are codified discourses like those of the Laskar Jihad or Christian FKM mentioned earlier or the more general panics aroused by accusations of Christianization and Islamicization that served as rallying 
cries or even captions orienting and providing a framework for perception and action. Many of the VCDs also contained authorizing discourses, slogans, and religious leaders-from the emotionally charged scene of a minister speaking in the charred hull of Ambon's landmark Silo Church following Bloody Christmas, or the voice of a man disciplining a visually incongruous crowd of jihadis by reciting the rules of jihad (no stealing, no felling of trees, no raping of women ... .), to imams soliciting donations, to energetic displays of the physical prowess of the cakalele warrior in performances of the famed Malukan war dance on-screen. ${ }^{110}$

Apart from such authorizing figures and discourses embedded in the VCDs, another aspect inherent to the effects of these and other media during the conflict are what Raymond Williams calls "social expressions in solution," as distinct from other semantic formations that he considers more evident and immediately available. ${ }^{111}$ Neither institutionalized nor reflexively present but tentative and incipient, such social expressions in solution-or "modes of affect and feeling attendant on emergent social processes" - inhabit a patchy, dispersed terrain, constituting community only as a potential. ${ }^{112}$ If they do congeal, then this is as structures of feeling that operate in tandem with other historical and political conditions and the aspirations, uncertainties, and contingencies of a given moment. In the context of Ambon's war, the attention of those who watched such VCDs as I witnessed, among others, at a screening in an ustad's home in Manado and, therefore, at a relative distance from Ambon's violence, was acute and affectively charged. ${ }^{113}$ Their brutal graphics and unambiguous visualization of victimization made the VCDs, on both sides, key components of social expressions in solution in which the tendency to produce a strong sense of the communal-however transient-was overdetermined.

One of the most professional VCDs, called North Maluku's Suffering, graphically intimates the kind of fluid, contingent expressions in solution that must have suffused the Muslim collectivity congealed on-screen. ${ }^{114}$ There, the gathering of people is bent to the common task of jihad in North Maluku but, I believe, in another situation, just as easily dispersed. Visibly at least, this public is an ad hoc collection of eclectic affinities. ${ }^{115}$ While everyone present, primarily men but also a few women, is dressed more or less in white, some appear orthodox and sober, others are inscribed from head to waist with ajimat (magical charms dating to the Crusades), ${ }^{116}$ some wear Saudi-style dress, others are wrapped in Palestinian headscarves, and still others exhibit Jihad-Central Javanese Yogyakartan style. Several carry Philippine Moro-type machetes, others have bows and arrows or spears, some have AK-47s, and a few even wield plastic guns, perhaps for their effect on unsuspecting audiences. 
In sociological terms, the question of the VCDs' effects on those who engaged them is, at least in part, one of mobilization or another way of asking how the mass appeal of the VCD genre shaped perception and action during the war. Compelling evidence from the conflict in Poso, Central Sulawesi, that, much like Ambon, played itself out along religious lines, suggests how only a small group of poorly organized men is capable of galvanizing a large segment of the population. ${ }^{117}$ Also that such group is often responsible for the majority of the killings, implying that most people implicated in collective violence are not themselves drawn to kill others. ${ }^{118}$ Nonetheless, as in Ambon, it seems to have been the case that hundreds of Protestant men joined vigilante brigades and committed-or at least actively participated in-gruesome acts of violence. ${ }^{119}$ Although not a central concern here, this means that it is crucial to recognize different levels of engagement, commitment, and action in the production of violence. More importantly, how forms of imagination, discourse, and imagery in inciting and perpetuating violence-the focus of this chapter rather than sociology per se-are much more broadly dispersed across a given population. This is a dimension of violence that is often underestimated or not given the attention it deserves by observers and analysts of violence, whether those employed by official government bodies, NGOs, or scholars, as I suggest above.

Another example of the imagination that appears to have suffused the city during the war are what I call anticipatory practices or the compulsive need to interpret and mine just about everything for hidden meaning, to see any trivial occurrence as a sign or omen of what might come or a hyperhermeneutic. ${ }^{120}$ There is, relatedly, the drive to produce signs (head ties, graffiti, and the like) for one's own group, for other social actors, for larger relevant audiences, and, not the least, for the enemy Other. Lest this seem too cerebral, the crucial dimension filling out this constellation of anticipatory practice is extreme, pervasive distrust: things are so thoroughly scrutinized because their nature and appearance are suspected of concealing something else. ${ }^{121}$ Again, as elsewhere in this chapter, the general climate of fear, insecurity, and mental and physical exhaustion that Ambonese inhabited on an almost continual basis during the war is important to bear in mind.

A prevalent assumption that things are other than they seem is nowhere more evident than in the discourse of disguise and revelation that followed an attack and ran through the more general talk about the conflict. A discourse of hidden depth, such talk revolved around the discoveries made when corpses were undressed, when the folds and pockets of garments were explored and turned inside out, disclosing a truer identity underneath - a jihad fighter with 
an army uniform under his robe, dates in a pocket indexing a devious connection to the Middle East, folded papers with talismans, and so on. ${ }^{122}$ A young Christian man who had participated in the fighting told me that, while initially Muslims wore white and Christians red, as the conflict dragged on, some Muslims wore red to make Christians think they were a friend rather than an enemy. ${ }^{123}$ This discourse on disguise fed into that of hidden depth and, besides red and white head ties, often involved army uniforms. In a clip I saw in 2003 , for instance, a stringer's video camera moves back and forth, repeatedly returning to and lingering over an army uniform laid out on the floor as if such persistent technological scrutiny might force it to yield another truth. This predicament-of being trapped in events beyond one's grasp and comprehension, of seeing no way out, of immersion in the thick context of terrible thingscomes through poignantly in my taped conversations with Malukan refugees from 2000 and 2001, in the voices and demeanor of Ambonese speaking on news reports before the 2002 Malino II Peace Agreement, and in the recollections of the men and women with whom I spoke in Ambon in September 2003 and during the time I spent in the city thereafter. "Everything is oppressed by rumor and the stories [that circulate] are always more fantastic than what is actually evident," is how one person characterized the atmosphere in wartime. ${ }^{124}$

More disturbingly, as the war went on, more and more people claimed to discern just under the surface of your ordinary Ambonese face its Christian or Muslim contours (see Chapter 4). A striking indication of the sedimentation of violence, this claim stands in sharp contrast to the assertion of an Ambonese, cited earlier in this chapter, who, at the onset of war, explained the Christian and Muslim practice of wearing differently colored head ties as due to the inability to tell each other apart-because, he explained, we are all Ambonese. While prepared in multiple ways and waiting, as it were, to happen, the hardening and primordializing of communal identities, evidenced in the naturalization of visible religious difference, must be understood as an outcome and not the origin of Ambon's conflict, as one sign, among many, of violence sedimenting and taking hold of the city. What this example also suggests is how, over time and to a much greater extent than was previously the case, the difference between Ambonese Muslims and Christians came to be something to be seen, something allegedly apparent beyond superficial distinctions of dress and habit. Such an essentialized understanding of religious difference was by no means absent in Ambon before the war. But it assumed a new volatile significance as violence provided religion with a highly elaborated, publicly visible dimension, one that helped to crystallize in ways visible to all the allegedly inherent difference between the city's Muslims and Christians. This 
essentialized visualization of difference is merely one outcome of the extreme perception that prevailed during Ambon's war.

\section{Official Peace}

On February 12, 2002, the Malino II Peace Agreement was signed after over three years of intermittent and devastating warfare. Of the Malino agreement's eleven points, no fewer than six invoke the rule of law, law enforcement, law and order, and human rights, while others refer to principles of transparency and fairness. The largely elite parties who took part in the two-day meeting convened by Indonesia's then coordinating minister of people's welfare, Jusuf Kalla, were familiar with the new laws brought into being under Reformasi and, along with many Indonesians, undoubtedly regarded the law, however flawed and limited its application in practice, as somehow inherently just. The weight and value accorded to the law in Indonesia (which, following Dutch colonial tradition, is a negara hukum or, in Dutch, a rechtstaat-literally, a state of law or a constitutional state) only increased as the dramatic changes around and following Suharto's fall were inflected by the prevailing global discourse on democracy, transparency, rights, and human rights in our contemporary Age of the International Community. ${ }^{125}$ Since the heady times of Reformasi, a great deal of attention has been paid to law, much of it focused on the courts, the police, and prosecution, in that order, and there have been some successes. As elsewhere, there is also a multitude of legally oriented NGOs focused on legal reform, corruption, rights, gender, and environmental issues at work in Indonesia, and a new energetic and promising generation of young legal reformers and activists. In recent years, social media provides another venue where people may mobilize to combat social injustice, although the success of such social media activism is often more restricted than it might seem since, in Indonesia at least, it depends on a particular felicitously conjunction of different factors. ${ }^{126}$

During Ambon's conflict, even after the imposition of civil emergency in June 2000, the security forces and police were, for a variety of reasons, virtually powerless when it came to taking legal action against those responsible for disorder. In a section on failure to uphold the law, an International Crisis Group report states that no fewer than 490 criminal cases were investigated and 855 suspects arrested as of July 2000, while a month later there was talk of holding trials on naval ships. ${ }^{127}$ More than a year thereafter, however, in November 2001, the governor described the courts as still paralyzed and admitted that under the circumstances the law could not be upheld. In April and May 2001, some symbolic legal steps were taken against extremist leaders on both the 
Muslim and Christian sides but, for different reasons in each case, prosecution has not been successful. What we have, in other words, is, on the one hand, a genuine regard for the law and repeated appeal to the judiciary as a privileged instrument deemed capable of restoring order and, on the other, a legal vacuum in terms of the means to enforce the law, along with considerable resistance to change by those schooled in the old system, and, in Ambon, until 2003, the ongoing presence of the armed forces under civil emergency, which are generally known for lending their support to local clients.

Throughout the conflict, multiple attempts were made to reconcile the warring parties, many of which appealed to grounds other than the law that were seen as potentially offering a solution or alternative to the war. These include customary law, most notably through the invocation of the pela blood brother alliances and the reinstitution of the older raja system of rule under Law 32/2004 that was part and parcel of decentralization in Maluku. ${ }^{128}$ Other arenas of reconciliation and peacemaking include the mass media through the broadcasting of pro-peace public service announcements on radio and television, projects advocating peace journalism and more neutral forms of reporting, and the interventions of various charismatic leaders on both sides who at different moments and through a variety of means tried to stop the fighting. ${ }^{129}$

It is difficult to evaluate how much significance, in the end, should be attributed to the relative success of the Malino agreement and its appeal to the law, given that this agreement benefitted from the relative calm imposed over time by the civil emergency and was met with skepticism by many ordinary Ambonese, who saw it as yet another elite move that only minimally touched on their problems. Notably, Ambonese I spoke with in September 2003, when the violence was still a recent memory, spoke of four and not three years of war and insisted that whatever calm existed in the city was more than anything else the result of the extreme fatigue among the city's population and the feeling that they had suffered enough-and, although this was not mentioned, without any clear advantage on either side. ${ }^{130}$ Others, testifying to the appeal of conspiracy theories in Indonesia, attributed Ambon's troubles to meddling by outsiders, especially to the operation of otherwise unspecified politics in Jakarta. "When they beat drums in Jakarta, we dance in Maluku," is how one minister put it. ${ }^{131}$ Yet, however important the peace accord might have been in establishing the relative détente that prevailed from early 2002 in Ambonbarring a number of major disturbances thereafter-not just one but at least a hundred Malinos were needed, a local cultural activist insisted, to remake a city that had been so radically transformed and disfigured by war, not the least by the enormous Jesus pictures that sprung up along its streets during the 
violence. ${ }^{132}$ Another instance of amplification, these pictures offered clarity and even solace for Protestants caught up in war's uncertainty and its aftermath. But for all their monumental posturing and contribution to change in the city, the peace and normality that has gradually consolidated in Ambon emerged not out of one hundred but out of the many more mini-Malinos that occur every day-from the minute gestures of hospitality and mutual acknowledgment that connect neighbors and the exchange of pleasantries and passing conversations among people on public transportation and in markets to the fading of the memories and trauma of conflict and crisis, including their expression on Ambon's walls, to which I now turn. 


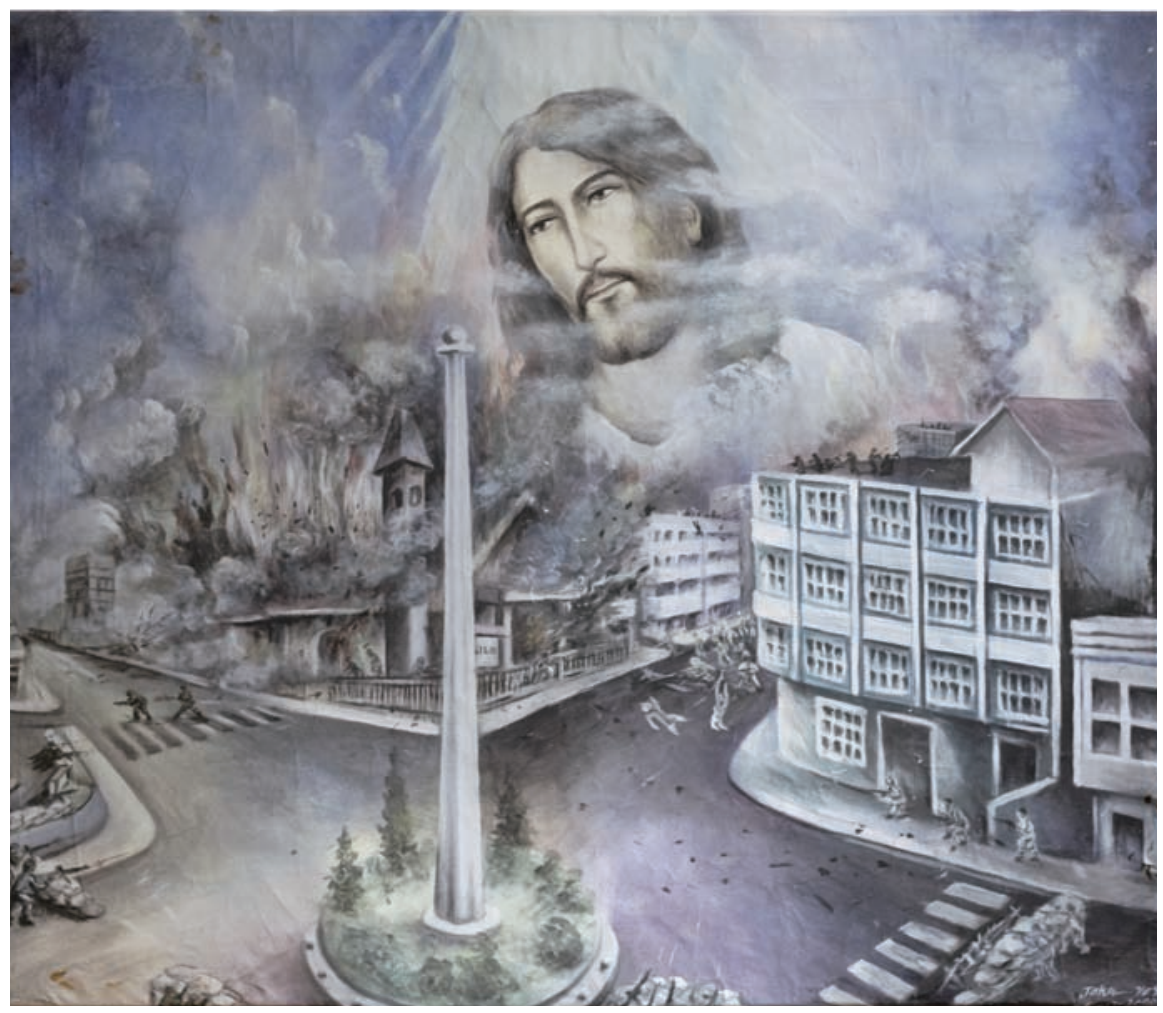

Figure 6. Painting on canvas by Jhon Yesayas, Ambon, 2005. Photo by Danishwara Nathaniel. One day when discussing his street art with me, Jhon mentioned that whereas his postwar murals and billboards were "comforting," those he did during the war depicted the violence in the city, as he went on to recall painting with bullets flying around him. I asked if he could do a painting for me like the ones he did during the war. It is the only painting I commissioned for this project. The painting, reproduced here, shows the attack on Ambon's GPM Silo Church on December 26, 1999, an event often referred to by Christians as "Bloody Christmas." When I showed up in early August 2005 to collect the painting, Jhon was adding a few final details-small figures crouching behind the barricades of the Christians, rocks and debris scattered in the street, cracks running up the side of a building. He explained that the scene "should not look too clean, so that it would be obvious that the atmosphere was terrifying." Expressing regret that the painting was small, he mentioned that he would like to do the same picture on a large scale. (Notes from an interview with author, Ambon, Indonesia, August 3, 2005.) 